\title{
Preliminary Reflection on Basic Principle of Operation Management for Public Work Infrastructure Asset Management
}

\author{
Ria Asih Aryani Soemitro ${ }^{1, a)}$ \& Hitapriya Suprayitno ${ }^{1, b)}$ \\ ${ }^{1)}$ Civil Engineering Department., Institut Teknologi Sepuluh Nopember (ITS), Surabaya, Indonesia.
}

Correspondance : ${ }^{a)}$ ria@ce.its.ac.id \& ${ }^{b}$ suprayitno.hita@gmail.com

\begin{abstract}
Public Works Infrastructure is vital for the life of a region. Therefore, it needs to be well operated. The knowledge or science of Operation Management is well developed, mainly for a Production Entreprises. The operation of infrastructure is different from those of the production enterprise. Therefore the Basic Principle of Operation Management for Public Works Infrastructure needs to be developed. Based on the system analysis principle, several findings have been produced. The infrastructure operation system consists of different system components. The infrastructure form, the infrastructure function, and the infrastructure operation characteristics, together, form the operation mechanism. The operation management manages the operation mechanism to achieve a certain level of operating performance measure. The infrastructure main function can be divided into to serve the user in the region or to produce something for the region. The function to serve can be of three basic forms: to flow something, to be used (in sense of to occupy at a certain time) by the users, or to be used for certain interactive activities. Regarding the variety of the nature of the infrastructure forms, functions, and operation characteristics, the infrastructure operation mechanism is also varied a lot in nature. Thus the operation management will be different for different types of infrastructures.
\end{abstract}

Keywords : infrastructure asset management, public works infrastructure, operation management, basic principle.

\section{INTRODUCTION}

Public Works Infrastructure is capital for the good life of a region and more of the country. Therefore, the Public Works Infrastructure must be always in good condition of functioning. This can be preserved if the infrastructure is well planned, designed, constructed, operated, and maintained. A good Infrastructure Operation is one of the conditions to be fulfilled, to have a good functioning of the infrastructure.

According to the Code on State Treasury, the ownership status of the Indonesian National or Regional Public Owned Goods (NPOG/RPOG) is under the Ministry of Finance. The NPOG/RPOG then is handed to different ministries and different regional government according to its function, to be managed (UU 1/04). Practically all of Public Works Infrastructures are Public Obligation Infrastructure. So, the public works infrastructure must always have the public. As public owned, the public works infrastructures are managed by different governmental levels, either national, provincial, regency, or city. The management of this Public Works Infrastructure must be by the Government Regulation on Management of NPOG and RPOG (PP 27/14).

Infrastructure \& Facility Asset Management (IFAM) is a knowledge, science, and program to manage infrastructure and facility, along its life cycle. The main objective of the 
IFAM is to ensure that the infrastructure and facility can sustainably well function, economically, efficiently, effectively, while still following the green principle. All the potential risks must be considered. The word management implies the hard management deals with the infrastructure and the soft management deals with the infrastructure managing organization (Soemitro \& Suprayitno2018; Suprayitno \& Soemitro 2018).

Several examples of Public Works Infrastructure miss-operation can be mentioned here. The inadequate control of the Lamong River generated a sudden flood to the riverain in the year 2019. Hundreds of houses must be left by the residents (Baihaqi 2019). Temporary Waste Disposal Point (TWDP) Sungai Belo is located next to Belo River and it served Tresono Traditional Market and Tresono Village in Kabupaten Batang. Due to the miss operation of waste transportation to the Final Waste Disposal Point (FWDP) caused the over piling-up of the TWDP. The TWDP Sungai Belo needs to close and has been closed (Indriani 2018). A lot of Public Apartments in Jakarta have potable water supply problems. It seems this is due to the miss operation of Potable Water Enterprise (AWS 2015). Jakarta and the surrounding area experienced a serious electricity shut-down for around two days in the middle of August 2019. It seems it was due to a miss operation (Fea 2019). Gubernur Suryo street in Surabaya, temporarily on 8 October 2018, experienced heavy traffic jam, due to Labour Demonstration (Anonim 2018). It can be seen that Operation Management is vital for a good function of infrastructure as the main objective of the IFAM.

Classic Operations Management has been deeply developed, in the Management branch of Economics knowledge, to deal with the operation of manufacturing activity (Stefanutti 2015). Public Works Infrastructures do something and need to be operated, but none of them are manufacturing activities. Therefore, knowledge and science which has been developed in Classics Operations Management cannot be applied in Infrastructure Asset Management. Meanwhile, the miss operated infrastructure can produce significant trouble.

Therefore, the Public Work Infrastructure needs to well operate. A Special Operation Management knowledge for IAM needs to be developed. This paper presents the result of an attempt to develop a Preliminary Reflection on the Basic Principle of Operation Management for Public Works Infrastructure Asset Management.

\section{RESEARCH METHOD}

The research was executed by following these steps, i.e. research objective designation, related and pertinent literature study, concept development, conclude the result. Four pertinent related concepts were studied. Concept development was done by using the system analysis method, by derivating the system elements and identifying the correlation of each element.

\section{LITERATURE REVIEW}

Four basic literature reviews are needed for this research, i.e. Management, Operation, Management, Management Notion in Civil Engineering, and Basic Principle of Infrastructure Asset Management.

\section{Management}

There a lot of text defining management. The most simple is cited here. Management is a process done by an organization or a group of people as a task force to achieve its objective (Priyono 2007; Carpenter, Bauer \& Erdogan 2012).

Management, in general, knows four Basic Functions of Management: Planning, Organizing, Actuating, and Controlling. In general, Management also knows several levels of management: low management, middle management, and top management (Priyono 2007). 


\section{Operation Management}

Operation Management is already well researched and developed. Operation Management is normally defined as knowledge and program to manage the operation of a manufacturing enterprise. This includes inventory, operations planning, manufacturing management, and distribution \& logistics. About the manufacturing activity itself, the discussions are already cover about break-even point, agile manufacturing, lean manufacturing, just-in-time, etc (BTC 2015; De Felice et al 2013; Stefanutti 2015).

\section{Management Notion in Civil Engineering}

The word "management" is used rather extensively in Civil Engineering. The word "management" is used for example for the following cases (Brierly 2008; CalRecovery 2005; Flaig \& Lark 2000; Goss \& Campbell 2008; Ritz 1994; Schliessler \& Bull 2004; Souza et al 2017, Suprayitno, 2014).

- River Management: to manage the river to maximize the benefits and to minimize the negative impact, by programming upstream forestation, by developing embankment protection, by developing dams, etc.

- Road Network Management System: to manage the road network by installing the road status, road functional class, road class, installing road sign and marking, installing traffic light following traffic management regulation, maintenance system, etc.

- Solid Waste Management System: to manage the community solid waste management system by installing the final processing installation, intermediate waste posts, solid waste transporting system, etc.

- Bridge Management System:

to manage a bridge: link status, maximum loading, inspection for maintenance, bridge sway, and deflection monitoring system, etc.

- Traffic Management:

to manage urban traffic: traffic volume, one-way system, no stop, no parking, signalized intersection, zebra cross, pedestrian walk, etc.

- Construction Management:

to manage construction work: project planning, construction method, heavy equipment, etc.

\section{CONCEPT DEVELOPMENT}

\section{Extension of IAM Basic Principle}

The Basic Principle of IAM definition seems needs to be extended, added by the four basic functions of management: planning, organizing, actuated, and controlling and Management Performance Measure.

\section{Concept Development Steps}

The Concept Development follow the following steps: understand the infrastructure form, function, operation mechanism, and operation characteristics. The next step is to formulate the operation management and operating performance measure.

A reflection on four types of infrastructure as examples of four Public Works Infrastructure families was analyzed. Those are irrigation networks, road networks, solid waste management, and low cost rental public apartment. 


\section{General Public Works Infrastructure}

In Indonesia, the Ministry of Public Works and Public Housing covers the following four families of infrastructure.

- Water Resouces Infrastructure: dam, weir, irrigation network, swamp irrigation, etc.

- Road Infrastructure: road network, bridge, road tunnel, etc.

- Housing Infrastructure: sanitation infrastructures, drainage network, potable water supply installation, green area, etc.

- Public Housing: public low-cost rental apartment, public low-cost apartment, low-cost housing estate, etc.

\section{Basic Principles of Operation Management for Public Works Infrastructure}

Operation Management is how to operate an infrastructure, to be able to always function well. How the infrastructure work depends on the Infrastructure Mechanism. While the Infrastructure Mechanism is a function of the Infrastructure Function, Infrastructure Form, and Operation Characteristics. Operation Management then is formulated as How the Operation Mechanism should be regulated to achieve a good Operation Performance. Therefore, a system of Operation Performance Measure must be formulated. This reflection is presented as a diagram in Figure 1 below.

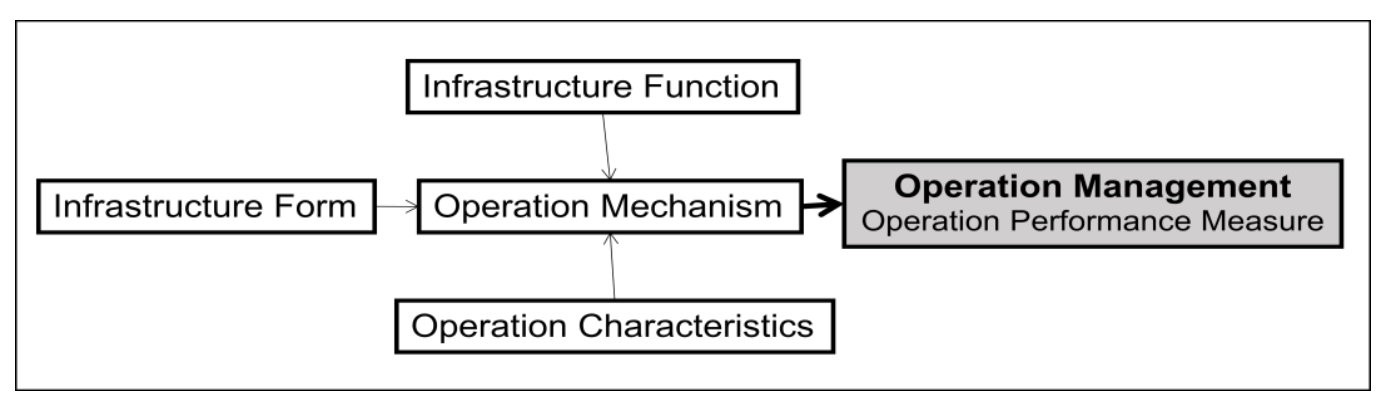

Figure 1. Diagram of Operation Management

\section{Basic Principles of Operation Management for Irrigation Network}

The Irrigation Network Infrastructure covers a certain Irrigation Area. The network itself consists of a weir, built on the river, connected with the primary irrigation channel. The primary channel is branched into several secondary channels, and the secondary channels are branched into several tertiary channels. Each channel branching is equipped with irrigation distributing and/or tapping sluices. Irrigation Network Infrastructure is illustrated in Figure 2 below. 


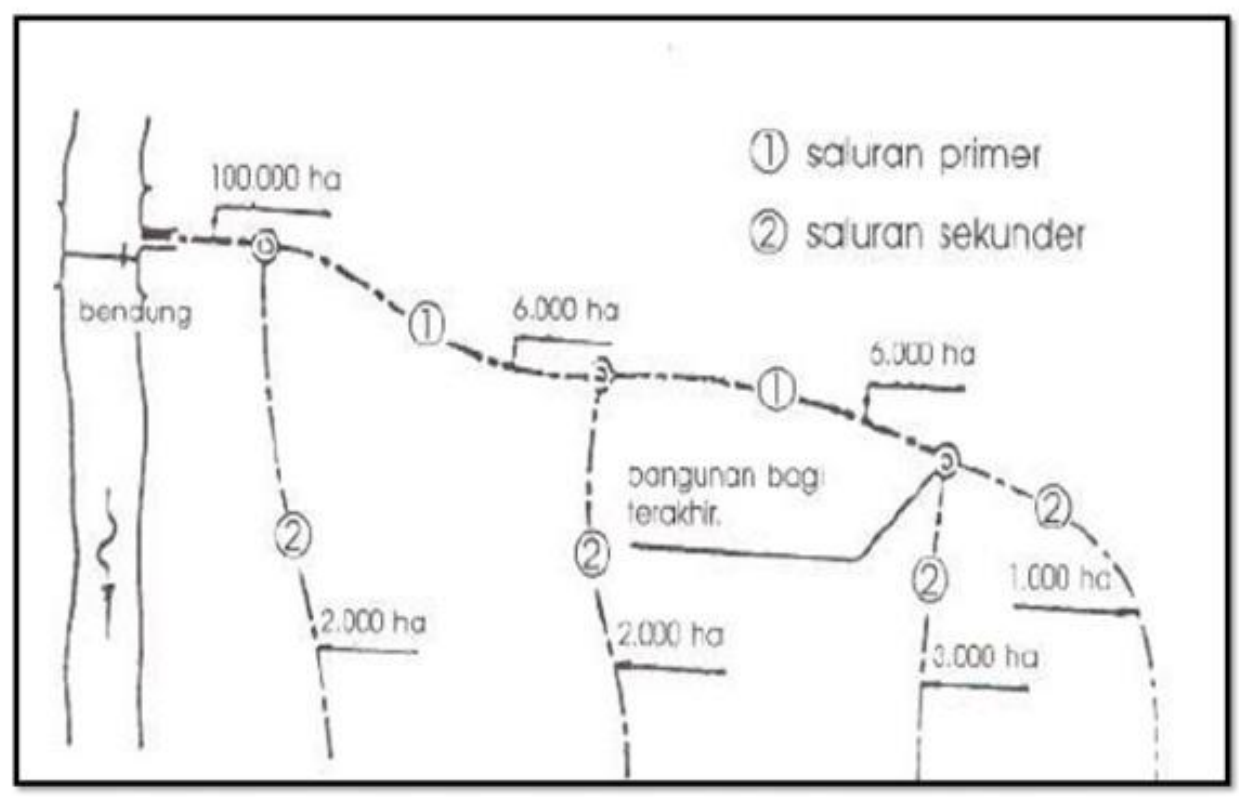

Figure 2. Illustration of Irrigation Infrastructure Network

The main function of the Irrigation Network is to flow irrigation water, tapped from the weir on the river, to different blocks of paddy field at a certain sum, time and period defined.

The operation mechanism is started with getting water from the intake at the weir and then distributed to different irrigation channels in the function of the water needed. In each channel branch, there is an irrigation tapping and/or distributing sluices. So ensuring the water distribution at a volume, time, and period needed is by regulating the water distribution in each irrigation sluice.

The Operation Characteristics are consists of differents water needs for different block, different water availability for a different season, water flow characteristics in each irrigation channel.

The Operation Performance Measure can be formulated as the fulfillment of the water needed by each rice field, the reality of the water needs fulfillment and the infrastructure load factor for each of the components of the irrigation infrastructure network.

\section{Basic Principles of Operation Management for Road Network}

The Road Network Infrastructure covers a certain Service Area. An urban road network consists of the roads, the intersections, the bridge, the tunnel, the pedestrian facilities, the road drainage system, and the road facilities and equipment, such as marking, sign, signal, bus stop, parking. The road itself is classified into several classifications: toll road and non-toll road, primary and secondary network, road function, road status, and road class. An illustration of a road network is presented in Figure 3 below. 


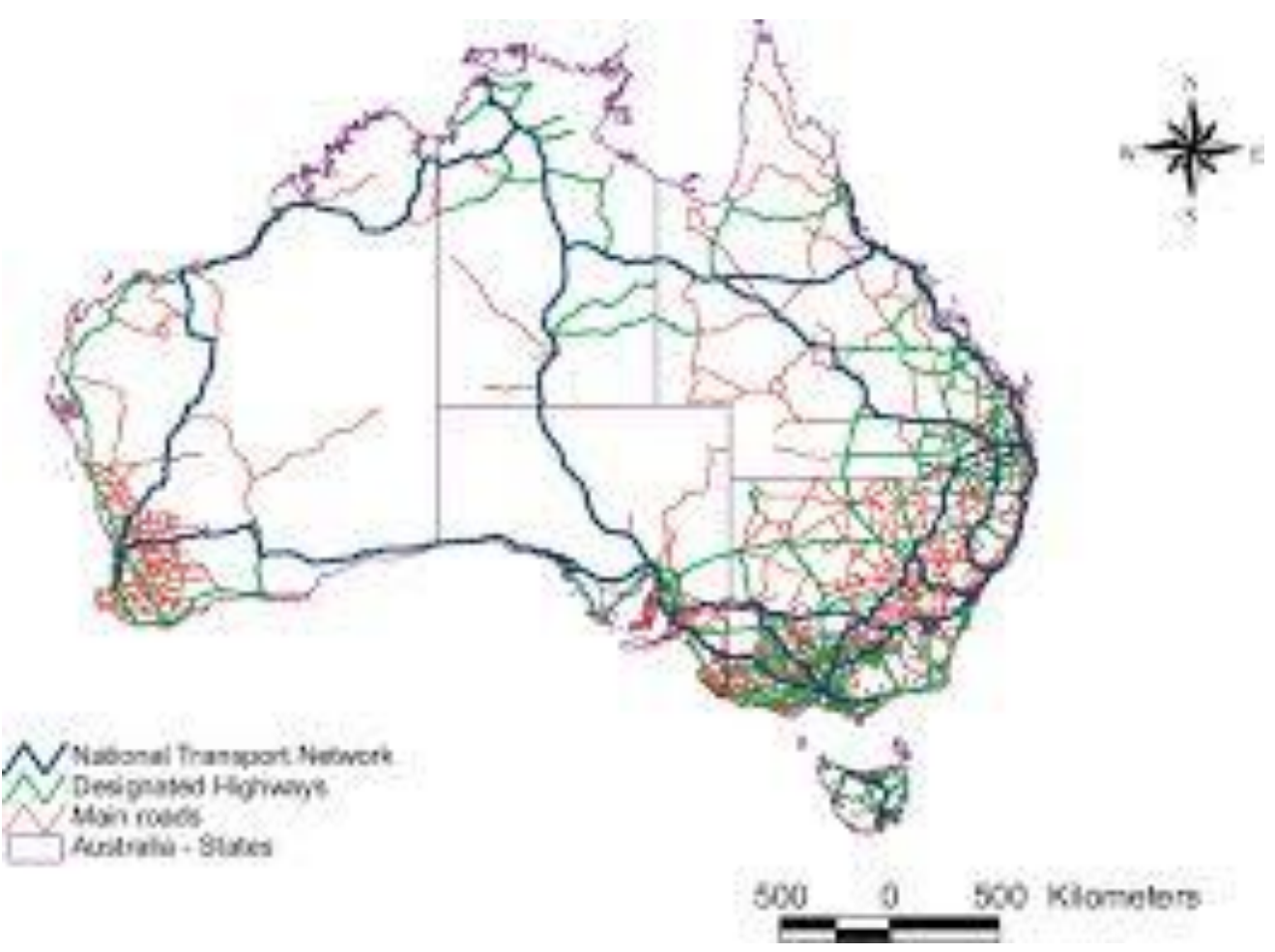

Figure 3. Example of Road Network Map

The main function of the road network is to flow different traffic the intercity traffic, the urban traffic, the freight traffic, the passenger traffic, the truck traffic, the private car traffic, the motorcycles traffic, and the public transport traffic.

The operation mechanism is just let the traffic flow according to the local traffic regulation set for the network. The local traffic regulation consists of regulating the network allowed for truck circulation, oneway traffic, regulate traffic signal network, speed limitation, etc.

The Operation Characteristics consists of various traffic origin-destination, hourly traffic volume variation, various traffic volume on each street, various modes composition on each street, public transport line and volume, etc.

The Operation Performance Measure is set consists of road traffic loading factors, traffic speed, delay, stops, travel time, etc.

\section{Basic Principles of Operation Management for Water Supply}

The Water Supply Infrastructure is planned and designed to serve a certain serving area. The infrastructure, in general, consists of water treatment installation, water reservoir, transmission pipe, distribution network, water sources, and water intake. The water supply infrastructure network is illustrated in Figure 4 below. 


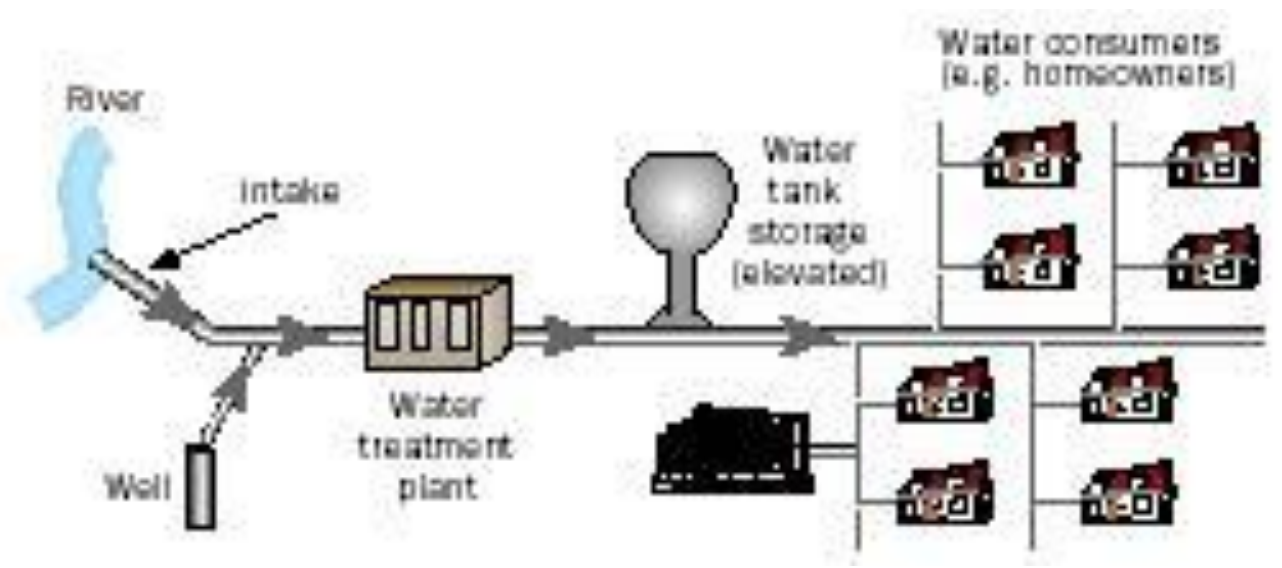

Figure 4. Illustration of Water Supply Infrastructure Network

The Water Supply Installation's main function is to take water from a certain source, normally a river, to treat the water to be clean water and to supply the clean water to the clients from the whole serving area.

Operation Mechanisms consist of tapping the water from the source, to treat the water to be clean, to dispose of the water into a water reservoir, to transmit the water into a different block of the serving area, to distribute the clean water into the clients. The water treatment consists of water sedimentation and coagulation, water aeration, water chloorifying.

The Operation Characteristics are due to quality and quantity variation of raw water, water treatment capacity, and performance, water reservoir capacity, condition of transmission and distribution facility, clean water demand variation along the day, the week and the year, different block, etc.

The Operation Performance Measure should be set consists of the water intake performance, water treatment performance, water distribution performance, and water quality regularity and reliability, and the network loading factor, etc.

\section{Basic Principles of Operation Management for Low-Cost Rental Public Apartment}

The Low-Cost Rental Public Apartment (LCRPA) usually exists in a block of apartments consist of several apartment buildings. The whole block consists of the apartments equipped with the parking facilities, social areas, sanitation facilities, electrical power facilities, the access road, etc. An aerial photo of a Low-Cost Rental Public Apartment Block is presented in Figure 5 below.

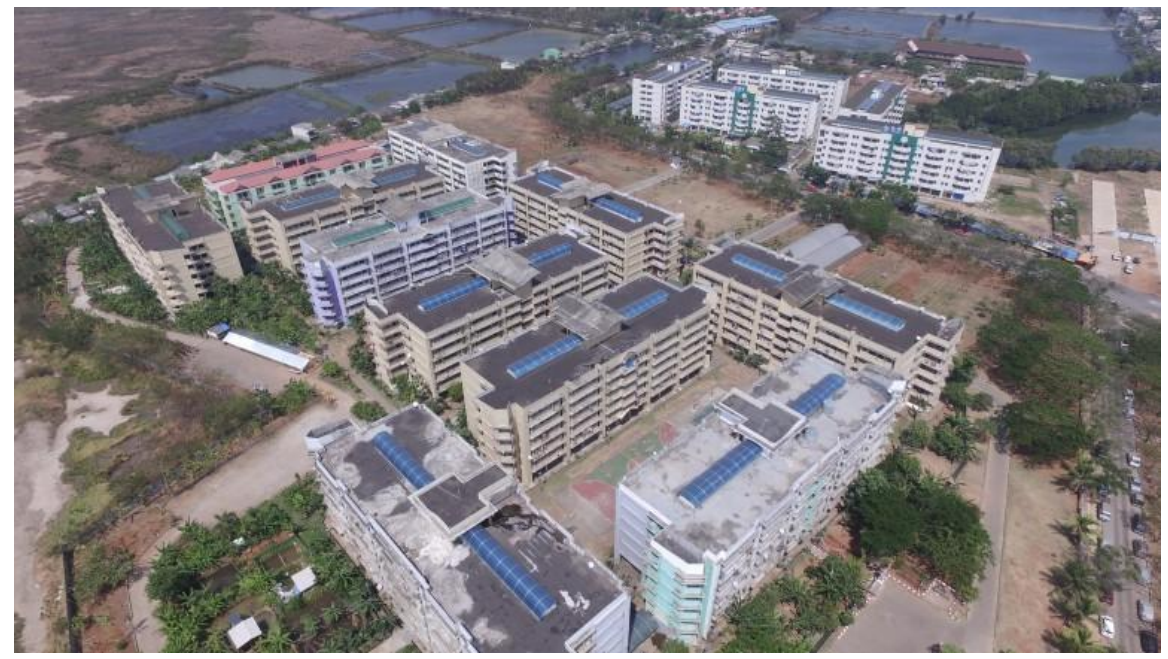

Figure 5. Aerial View of Low-Cost Rental Public Apartment 
The main function of LCRPA is to be used by low economy households, with a certain level of income and family size. The security, safety, and comfort must be ensured.

The Operation Mechanism for the LCRPA consists of the new resident application and acceptance, the rental payment, resident's complaints, office opening hours, the operation of sanitation facilities, the operation of parking facilities, etc.

The Operation is characterized by apartment complex facilities, number of buildings, number of apartments, number of families, family size, family age, number of vehicles, activity hours, etc.

The Operation Performance Measure can be formulated as capacity, loading factor, safety, security, comfort, sanitation performance, electrical power performance, etc.

\section{Other Elements fo Operation Management}

It must be noted that, as all management work, Operation Management involves the work of Operation Planning, Operation Actuation, Operation Evaluation, and Operation Improvement. The infrastructure condition for operation needs to be evaluated periodically. Inspection management needs to be installed for the maintenance program.

Regarding the infrastructure function, these can be classified as three types of functions: to flow something, to produce something, to be used by the user.

\section{CONCLUSIONS}

The Preliminary Basic Principle of Operation Management for IAM has been developed. Several main conclusions are written below.

- Operation Management is managing the Operation Mechanism of the Infrastructure.

- Operation Mechanism is dependent on Infrastructure Function, Infrastructure Form, and Operation Characteristics.

- Operation Management must be controlled by Operation Performance Measure.

- Operation Management = Operation Mechanism Management + Managing Organization Management.

- Operation Management needs to be planned, actuated, evaluated, improved, and developed.

- Different infrastructure has different functions, different forms, different operation mechanism, and different operating characteristics.

- Public Works Infrastructure's main functions can be grouped into: to flow something, to produce something, or to be used by users.

- Infrastructure Operation Management needs to be deepened and extended for each type of infrastructure.

Further curiosity: developed operation management, basic principles of operation management for different infrastructure, develop a general theory of infrastructure operation management, the economics of infrastructure operation management, etc.

Notes. This paper has been presented in SENIMA 4 - 2019 Univesitas Negeri Surabaya. This paper is part of working papers for developing the knowledge and science of Infrastructure \& Facility Asset Management.

\section{REFERENCES}

Anonim (2018). "Breaking News - Jalan Gubernur Suryo Surabaya Macet Karena Ada Demo Buruh”. Surya.co.id, Senin, 8 Oktober 2018, 13:28 WIB.

AWS (2015). "Banyak Rusub Sulit Dapat Air Bersih, Ahok : Jujur PAM itu Payah". DetikNews, Selasa, 5 Mei 2015, 18:25 WIB.

Baihaqi, A. (2019). "Sungai Lamong Meluap, Ratusan Rumah di Surabaya Kebanjiran". DetikNews, Jum'at, 3 Mei 2019, 14:45 WIB. 
Brierly, G. (2008). "Geomorphology and River Management". Kemanusiaan 15(28) 2008, pp. 13-26.

BTC (2015). Principles of Operation Management. Business \& Training Center. Portsmouth.

Carpenter, M., Bauer, T.\& Erdogan, B. (2012). Management Principle. (http://2012books.lardbucket.org/). Downloaded 24 August 2018.

CalRecovery (2005). Solid Waste Management. UNEP - United Nations Environment Programme.

De Felice, F., Monfreda, S., Petrillo, A., Nenni, M.E., Iannone, R., Introna, V., Giuiusa, A. \& De Carlo, F. (2013). Operations Management. The Open University of Hong Kong. Hong Kong.

Fea (2019). "Netizen Mengeluh Listrik Padam di Jakarta dan Sekitarnya". CNN Indonesia, Rabu, 14 Agustus 2019, 02:34 WIB.

Flaig, K.D. \& Lark, R.J. (2000). "The Development of UK Bridge Management System". Proceeding of Institution of Civil Engineers Transport 2000, 141, May, 99-106.

Goss, R.C. \& Campbell, H.L. (2008). “The Evolution of Residential Property Management: From Caretaker to Income Maximization Manager". Housing and Society, Vol. 35, No. $1,2008$.

Indriani, D. (2018). "Sampah Menumpuk dan Mencemari Lingkungan Sekitar, TPS Sungai Belo Batang Ditutup". TribunJateng.com, Jum'at, 30 Maret 2018, 12:56 WIB.

PP 27/14. Peraturan Pemerintah Republik Indonesia Nomor 27 Tahun 2014 tentang Pengelolaan Barang Milik Negara/Daerah.

Priyono (2007). Pengantar Manajemen. Zifatama Publisher. Sidoarjo.

Ritz, G.J. (1994). Total Construction Project Management. McGraw-Hill. Boston.

Schliessler, A. \& Bull, A. (2004). Road Network Management. GTZ German Technical Cooperation \& UN-ECLAC United Nations Economic Commission for Latin America and the Caribbean.

Soemitro, R.A.A. \& Suprayitno, H. (2018). "Pemikiran Awal tentang Konsep Dasar Manajemen Aset Fasilitas". Jurnal Manajemen Aset Infrastruktur \& Fasilitas, Vol. 2, Suplemen 1, Juni 2018, Hal. 1-14.

Souza, Brennand, Yokoyama, Donato, Madeira \& Villas (2017). "Traffic Management System: A Classification, Review, Challenges, and Future Perspective". International Journal of Distributed Sensor Networks 13(4) 2017.

Stefanutti, B. (2014). Principles of Operation Management. Consept - Consulenza e Planificazione Technologica. Padova.

Suprayitno, Hitapriya (2014). Metoda Penilaian Kualitas Jaringan Jalan Utama di Wilayah Kabupaten. Disertasi RC 09-3399. Jurusan Teknik Sipil, Institut Teknologi Sepuluh Nopember. Surabaya.

Suprayitno, H. \& Soemitro, R.A.A. (2018). "Preliminary Reflexion on Basic Principle of Infrastructure Asset Management". Jurnal Manajemen Aset Infrastruktur \& Fasilitas, Vol. 2, No. 1, Maret 2018, pp. : 1-10.

Suprayitno, H. \& Soemitro, R.A.A. (2019). "Reflection on Basic View of Public Infrastructure for Infrastructure Asset Management in Indonesia". Jurnal Manajemen Aset Infrastruktur \& Fasilitas, Vol. 3, Suplemen 1, Juni 2019, Hal. : 15-24.

UU 1/04. Undang-Undang Republik Indonesia Nomor 1 Tahun 2004 tentang Perbendaharaan Negara. 
(e)ISSN 2656-8896 (p)ISSN 2656-890X

Journal of Infrastructure and Facility Asset Management - Vol. 2, Suplement 1, December 2020 